\title{
A POLICY ANALYSIS OF FEE-SHIFTING RULES UNDER THE INTERNAL REVENUE CODE
}

\author{
RICHARD L. SCHMALBECK* \\ AND GARY MYERS**
}

Until recently, the costs of hitigating federal tax cases were borne exclusively by the parties who incurred thein, regardless of whether the government or the taxpayer prevailed in the hitigation. This practice reflects the application to tax disputes of the "American rule" against fee shifting. ${ }^{1}$

Although the American rule continues to be predoininant in the tax area, it has been inodified in important respects. An explicit fee-reimbursement rule, benefiting prevailing taxpayers in cases in which the government is found to have acted unreasonably, was added to the Internal Revenue Code (IRC) by the Tax Equity and Fiscal Responsibility Act of 1982 (TEFRA). ${ }^{2}$ TEFRA also increased substantially the penalties that could be imposed on taxpayers who are found to have instituted tax litigation on frivolous grounds, or primarily for delay. ${ }^{3}$ The provisions are not precise counterparts of each other: one is a true fee-reinburseinent rule, while the other is a penalty provision that is not directly tied to litigation costs. Nevertheless, the rules are similar in their effects on incentives to litigate tax cases.

* Professor of Law, Duke University School of Law.

** Law Clerk to the Honorable Gerald Bard Tjoflat, United States Court of Appeals for the Eleventh Circuit. B.A. 1984, New York University; M.A., J.D. 1986, Duke University.

This article grew out of an analysis of fee-shifting proposals prepared by Professor Sclımalbeck at the request of the Senate Judiciary Committee. That analysis culminated in a letter dated March 17,1986 on this subject to Sen. Charles E. Grassley of Iowa, then Chairman of the Judiciary Committee's Subcommittee on Administrative Practice and Procedure. A copy of this letter is on file with the Duke Law Journal.

The authors wish to thank their respective colleagues, Thomas Rowe and Richard Winters, for their helpful comments on an earlier draft of this article. In addition, Professor Schmalbeck gratefully acknowledges the research assistance of Robert Chanis, Jeffrey Lawyer, and Laurel Solomon.

1. The rule is well entrenched. As John Leubsdorf put it: "As far back as one can trace, courts in this country have allowed winning litigants to recover their litigation costs from losers only to the extent prescribed by the legislature." Leubsdorf, Toward a History of the American Rule on Attorney Fee Recovery, LAw \& CONTEMP. ProBs., Winter 1984, at 9, 9.

2. Pub. L. No. 97-248, § 292(a), 96 Stat. 324, 572.

3. See id. $\$ 292($ b), 96 Stat. at 574 . The maximum penalties were increased from $\$ 500$ to $\$ 5000$. 
This article begins with a brief description and history of these provisions, followed by an analysis of their impact on litigation decisionmaking in the tax area. We argue that the present mix of fee-shifting rules in tax cases represents an attractive hybrid of the American rule and the "Enghish rule," which normally allows recovery of costs by the prevailing party. The hybrid rule seems likely to deter parties from bringing poorly grounded cases to court without discouraging litigants with sounder positions. It thus combines the best features of each of the more traditional rules. After analyzing the hybrid rule, we discuss the recent changes to the rule made by the Tax Reform Act of $1986^{4}$ and argue that those changes, on balance, do not represent improvements over the original TEFRA rules, and may indeed prove troublesome in the coming years.

\section{FEe ShIFTINg UNDER THE IRC}

Under section 6673 of the IRC, 5 the Umited States is entitled to damages of up to $\$ 5000$ if a taxpayer institutes or maintains a proceeding in Tax Court "primarily for delay," if the taxpayer's position in the proceeding is "frivolous or groundless," or if the taxpayer has "unreasonably failed to pursue available administrative remedies." 6 The Tax Court has discretion in granting these awards, ${ }^{7}$ and the government has succeeded in obtaining damages in an increasing number of cases. ${ }^{8}$ The primary purpose of section 6673 is to penalize and deter taxpayers from raising frivolous claims in the Tax Court. 9

Under section 7430, the government must pay the prevailing taxpayer's "reasonable litigation costs" if the court finds that the govern-

4. See Pub. L. No. 99-514, $\S \S 1551$ (a)-(g), 1552(a), 100 Stat. 2085, 2752-53 (amending I.R.C. $\S \S 6673,7430(1982))$.

5. I.R.C. $\S 6673$ (1982), as amended by Tax Reform Act of 1986, Pub. L. No. 99-514, $\S 1552(a), 100$ Stat. 2085, 2753.

6. This last provision was added to section 6673 by the Tax Reform Act of 1986, Pub. L. No. 99-514, § 1552(a), 100 Stat. 2085, 2753.

7. See May v. Commissioner, 752 F.2d 1301, 1306 (8th Cir. 1985) (Tax Court has discretion to award damages under section 6673 , subject to appellate review for abuse of discretion).

8. See, e.g., Larsen v. Commissioner, 765 F.2d 939, $941-42$ (9th Cir. 1985); May v. Commissioner, 752 F.2d 1301, 1306-09 (8th Cir. 1985); Granzow v. Commissioner, 739 F.2d 265, 267-68 (7th Cir. 1984); Crain v. Commissioner, 737 F.2d 1417, 1418 (5th Cir. 1984); Oneal v. Commissioner, 84 T.C. 1235, 1244 (1985); Derksen v. Commissioner, 84 T.C. 355, 361 (1985); Beard v. Commissioner, 82 T.C. 766, 781 (1984); Coulter v. Commissioner, 82 T.C. 580, 586 (1984); Abrams v. Commissioner, 82 T.C. 403,413 (1984); Grimes v. Commissioner, 82 T.C. 235, 239 (1984); Sydnes v. Commissioner, 74 T.C. 864, 873 (1980), aff'd, 647 F.2d 813 (8th Cir. 1981); Greenberg v. Commissioner, 73 T.C. 806, 816 (1980); Wilkinson v. Commissioner, 71 T.C. 633,643 (1979).

9. See Sauers v. Commissioner, 771 F.2d 64, 67 (3d Cir. 1985), cert. denied, 106 S. Ct. 2286 (1986). 


\section{ment's position in the tax case is not "substantially justified."10 The}

10. I.R.C. $\S 7430$ (1982 \& Supp. III 1985), as amended by Tax Reform Act of 1986, Pub. L.

No. 99-514, $§ 1551,100$ Stat. $2085,2752-53$, provides as follows:

(a) In general-In the case of any civil proceeding which is-

(1) brought by or against the United States in connection with the determination, collection, or refund of any tax, interest, or penalty under this title, and

(2) brought in a court of the United States (including the Tax Court and the United States Claims Court),

the prevailing party may be awarded a judgment (payable in the case of the Tax Court in the same manner as such an award by a district court) for reasonable litigation costs in. curred in such proceeding.

(b) Limitations

(1) Requirement that administrative remedies be exhausted $\rightarrow A$ judgment for reasonable litigation costs shall not be awarded under subsection (a) unless the court determines that the prevailing party has exhausted the administrative remedies available to such party within the Internal Revenue Service.

(2) Only costs allocable to the United States-An award under subsection (a) shall be made only for reasonable litigation costs which are allocable to the United States and not to any other party to the action or proceeding.

(3) Exclusion of declaratory judgment proceedings

(A) In general-No award for reasonable litigation costs may be made under subsection (a) with respect to any declaratory judgment proceeding.

(B) Exception for section 501(c)(3) determination revocation proceedings-Subparagrapl (A) shall not apply to any proceeding which involves the revocation of a determination that the organization is described in section $501(\mathrm{c})(3)$.

(4) Costs denied where party prevailing protracts proceedings-No award for reasonable litigation costs may be made under subsection (a) with respect to any portion of the civil proceeding during which the prevailing party has unreasonably protracted such proceeding.

(c) Definitions-For purposes of this section-

(1) Reasonable litigation costs-

(A) In general--The term "reasonable litigation costs" includes-

(i) reasonable court costs, and

(ii) based upon prevailing market rates for the kind or quality of services furnished-

(I) the reasonable expenses of expert witnesses in connection with the civil proceeding, except that no expert witness shall be compensated at a rate in excess of the highest rate of compensation for expert witnesses paid by the United States,

(II) the reasonable cost of any study, analysis, engineering report, test, or project which is found by the court to be necessary for the preparation of the party's case, and

(III) reasonable fees paid or incurred for the services of attorneys in connection with the civil proceeding, except that such fees shall not be in excess of $\$ 75$ per hour unless the court determines that an increase in the cost of living or a special factor, such as the limited availability of qualified attorneys for such proceeding, justifies a higher rate.

(B) Attorney's fees-In the case of any proceeding in the Tax Court, fees for the services of an individual (whether or not an attorney) who is authorized to practice before the Tax Court shall be treated as fees for the services of an attorney.

(2) Prevailing party-

(A) In general-The term "prevailing party" means any party to any proceeding described in subsection (a) (other than the United States or any creditor of the taxpayer involved) which-

(i) establishes that the position of the United States in the civil proceeding was not substantially justified,

(ii)(I) has substantially prevailed with respect to the amount in controversy, or

(II) has substantially prevailed with respect to the most significant issue or set of issues presented, and

(iii) meets the requirements of section 504(b)(1)(B) of title 5, United States Code (as in effect on the date of the enactment of the Tax Reform Act of 1986 and applied by taking into account the commencement of the proceeding described in subsection (a) in lieu of the initiation of the adjudication referred to in such section).

(B) Determination as to prevailing party-Any determination under subparagraph (A) as to whether a party is a prevailing party shall be made-

(i) by the court, or 
government's liability is limited by several additional provisions: (1) attorney fees can be recovered only up to $\$ 75$ per hour, unless the court determines that special circumstances justify a higher rate; ${ }^{11}$ (2) expert witness fees can be recovered based upon "prevailing market rates," and in no event at a rate greater than the higliest government rate for expert witnesses; ${ }^{12}$ and (3) the cost of preparing engineering reports and the hike can only be recovered at the market rate. ${ }^{13}$ Section 7430 differs from section 6673 in several ways. First, section 7430 applies to tax disputes in any court, while section 6673 applies only to proceedings in the Tax Court. ${ }^{14}$ Second, under section 7430 the taxpayer must establisli that lie is a prevailing party and that the position of the United States was not substantially justified. ${ }^{15}$ In contrast, section 6673 allows the Tax Court to award damages to the government if the taxpayer's position was frivolous, the proceeding was instituted or maintained by the taxpayer primarily for delay, or the taxpayer failed to exhaust administrative

(ii) by agreement of the parties.

(3) Civil actions-The term "civil proceeding" mcludes a civil action.

(4) Position of United States-The term "position of the United States" includes-

(A) the position taken by the United States in the civil proceeding, and

(B) any administrative action or inaction by the District Counsel of the Internal Revenue Service (and all subsequent administrative action or inaction) upon which such proceeding is based.

(d) Multiple actions-For purposes of this section, in the case of-

(1) multiple actions which could have been joined or consolidated, or

(2) a case or cases involving a return or returns of the same taxpayer (including joint returns of married individuals) which could have been joined in a simgle proceeding in the same court, such actions or cases shall be treated as one civil proceeding regardless of whether such joinder or consolidation actually occurs, unless the court in which such action is brought determines, in its discretion, that it would be inappropriate to treat such actions or cases as joined or consolidated for purposes of this section.

(e) Right of appeal-An order granting or denying an award for reasonable litigation costs under subsection (a), in whole or in part, shall be incorporated as a part of the decision or judginent in the case and shall be subject to appeal in the same manner as the decision or judgment.

Id.

11. Id. $\$ 7430$ (c)(1)(A)(ii)(III) (1982 \& Supp. III 1985), as amended by Tax Reform Act of 1986, Pub. L. No. 99-514, § 1551(c), 100 Stat. 2085, 2752.

12. Id. $\S 7430(\mathrm{c})(1)(\mathrm{A})(\mathrm{ii})(\mathrm{I})$.

13. Id. $\S 7430(\mathrm{c})(1)(\mathrm{A})(\mathrm{ii)}(\mathrm{II})$. Prior to the enactment of the Tax Reform Act of 1986, section 7430 contained an overall limitation on fee recoveries of $\$ 25,000$ for any one dispute, and provided only that the fees paid to attorneys and expert witnesses, and the costs of any reports or studies, be reasonable. See id. $\S 7430(\mathrm{~b})(1)$, (c)(1)(A) (1982), amended by Tax Reform Act of 1986, § 1551(c), 100 Stat. 2085, 2752.

14. Compare id. $\$ 7430$ (a) (Supp. III 1985) ("any civil proceeding ... brought in a court of the United States (including the Tax Court and the United States Claims Court)") with id. § 6673 (1982) (proceedings in Tax Court).

15. Id. $\S 7430$ (a), (c)(2) (1982 \& Supp. III 1985), as amended by Tax Reform Act of 1986, Pub. L. No. 99-514, §1551(d), 100 Stat. 2085, 2752-53. In addition, the taxpayer inust exhaust any administrative remedies available to him. Id. $\S 7430(b)(1)(1982)$, as amended by Tax Reform Act of 1986, Pub. L. No. 99-514, §1551(a), 100 Stat. 2085, 2753. 
remedies. ${ }^{16}$ Finally, the amount and nature of the remedies differ. ${ }^{17}$ Despite these differences, however, sections 6673 and 7430 together provide a roughly equivalent warning to both sides in tax disputes: if a litigant's position falls outside the range within which good faith differences of opimion about legal or factual matters can be advanced, that litigant may be hable for the other hitigant's attorney fees.

\section{Fee-Shifting Rules and the Quantity of TaX Litigation}

In the United States, the general rule regarding attorney fees is that hitigants bear their own costs and successful parties are not entitled to awards of attorney fees. This approach is known, logically enough, as the "American rule."18 In Great Britain and nost of the rest of Europe, the general practice is to "let the costs follow the event"- that is, to impose all or a substantial part of both parties' costs on the losing litigant. ${ }^{19}$ This approach is known as the "English rule."

These rules raise two broad questions, one normative (Which is the better rule?) and the other positive (Which rule minimizes expenditures on hitigation?). Because the prevailing view in the United States is that

16. I.R.C. $\S 6673$ (1982), as amended by Tax Reform Act of 1986, Pub. L. No. 99-S14, $\S 1552(\mathrm{a}), 100$ Stat. $2085,2753$.

17. A maximum of $\$ 5000$ can be awarded under section 6673 ; section 7430 , in contrast, contains no explicit cap on fee awards. See supra note 10. Moreover, awards under section 6673 are essentially penalties that are not based on a specific finding of damages incurred by the government. See Sauers v. Commissioner, 771 F.2d 64, 67 (3d Cir. 1985) ("[U]nlike . . . an award of compensatory damages, an assessment of damages is not required before a penalty may be imposed."). But awards to taxpayers under section 7430 are based on a determination of the prevailing party's "reasonable litigation costs." I.R.C. § 7430(c)(1) (1982), as amended by Tax Reform Act of 1986, Pub. L. No. 99-514, § 1551(c), 100 Stat. 2085, 2752. See Prudential-Bache Sec., Inc. v. Tranakos, 593 F. Supp. 783, 786-87 (N.D. Ga. 1984) (allowing recovery of fees and costs incurred by innocent stake. holder who in good faith invoked interpleader statute to avoid multiple liability). Only litigation costs allocable to actions of the government, as opposed to actions of other parties in the proceeding, can be awarded under section 7430. See I.R.C. $\$ 7430$ (b)(2) (1982), as amended by Tax Reform Act of 1986, Pub. L. No. 99-514, § 1551(a), 100 Stat. 2085, 2752.

18. For a discussion of the nature and history of the American rule, see Alyeska Pipeline Serv. Co. v. Wilderness Soc'y, 421 U.S. 240, 247-71 (1975); Leubsdorf, supra note 1. Many statutory exceptions to the general American rule have been enacted in recent years. For a discussion of the justifications for fee shifting, see Rowe, The Legal Theory of Attorney Fee Shifting: A Critical Overview, 1982 DUKE L.J. 651.

A number of commentators have attempted to assess the general effects of various fee-shifting rules and the American rule. See, eg., Braeutigam, Owen \& Panzar, An Economic Analysis of Alternative Fee Shifting Systems, LAw \& CONTEMP. ProBs., Winter 1984, at 173; Rowe, Predicting the Effects of Attorney Fee Shifting, LAW \& CONTEMP. PROBS., Winter 1984, at 139; Shavell, Suit, Settlement, and Trial: A Theoretical Analysis Under Alternative Methods for the Allocation of Legal Costs, 11 J. LEgAL Stud. 55 (1982).

19. The statement in the text is a vast oversimplification, even as to practices in England itself. For a description of fee-shifting arrangements in twelve European countries, see Pfenningstorf, The European Experience with Attorney Fee Shifting, LAW \& CONTEMP. PROBs., Winter 1984, at 37. 
far too many resources are spent on litigation, there is a powerful tendency to allow the positive question to swallow the normative one. Under such an approach, the better rule is the rule that will produce lower expenditures on litigation, fewer lawsuits, and a higher settlement rate. This is likely to be particularly true as to the federal tax system because each of the hundred million or so returns filed annually represents a potential dispute.

Even in the tax area, however, litigation serves some useful purposes. Although they are detailed, the IRC and the Treasury Regulations cannot anticipate, with sufficient specificity to eliminate interpretive disputes, every factual situation that may arise. Courts not only resolve the specific disputes placed before them, but also provide guidance to unrelated taxpayers as to low their potential disputes may be resolved. In addition, an independent, expert court—and the Tax Court surely lias both of those qualities-can serve as a useful check on the discretion of an administrative agency to implement a complex statutory directive. Indeed, facilitating this process is one of the explicit notions behind the enactment of section 7430.20 In effect, Congress has determined that, at least in some circumstances, individual taxpayers should not be required to bear the costs of cliecking administrative excess.

On the other hand, because taxpayers never bear the full costs of the resources engaged in litigating their tax disputes, ${ }^{21}$ there is a great risk that those resources will be used excessively. The tax litigation situation, then, is one in which countervailing external costs and benefits can be identified. A priori, it is uncertain whether the external benefits of clear precedents and restraint of administrative discretion outweigh the external costs involved in subsidizing the court system. We will return to this point.22

First, however, let us examine briefly the narrower, positive question: Which fee rule will miminize litigation costs? Unfortunately, there is no consensus as to which rule produces less litigation. One might as-

20. The Ways and Means Committee specifically noted in its report on what was to become TEFRA that "fee awards in such tax cases [where the government has acted unreasonably] will deter abusive actions or overreaching by the Internal Revenue Service." H.R. REP. No. 404, 97th Cong., 1st Sess. 11 (1982).

21. The Tax Court is authorized to impose a fee of up to $\$ 60$ for filing a petition in that court. See I.R.C. $\$ 7451$ (1982). The Tax Court has exercised the full measure of this authority. See TAX CT. R. PRAC. 20(b). The Tax Court may waive this fee if the petitioner establishes his inability to make such a payment. Id. In any event, the fees do not begin to cover the cost of operating the Tax Court. For fiscal year 1987, during which it expected to dispose of 45,200 cases, the Tax Court sought an appropriation of $\$ 25,538,000$, or $\$ 565$ per case. The Budget of the United States Gov't, FY 1987 Appendix, at I-A25 to I-A26. This figure, of course, does not cover the government's costs in trying Tax Court cases, nor any of the costs associated with tax cases in any other federal court.

22. See infra text accompanying notes 38-40. 
sume from the apparently much larger volume of hitigation in the United States vis-a-vis Europe that the American rule produces more litigation. Such an inference would be unjustified, however, in view of the many factors - of which fee-shifting rules probably constitute only a minor one-that affect the overall volume and cost of litigation.

The most rigorous efforts that have been made to examine the effects of the Enghish and American rules on litigation expenditures are either contradictory or inconclusive. Steven Shavell analyzed the two rules in the context of two types of tort disputes: automobile accidents and accidents caused by ultrahazardous activities. ${ }^{23}$ Shavell tentatively concluded that the volume of litigation resulting from automobile accidents would be reduced by the Enghish rule, but that the volume of litigation resulting from ultrahazardous activities miglit well be increased.24 Professors Braeutigam, Owen, and Panzar concluded that movement from the American rule to the Englisli rule would increase total expenditures on litigation.25 Althougli their model yields many useful insights, the general applicability of this conclusion is limited by several of the model's simplifying assumptions, particularly the assumption that the parties are risk-neutral. ${ }^{26}$ Thomas Rowe, using a less mathematical analysis that attempted to include consideration of risk-aversion, detected "some basis for a tentative conclusion" that fee shifting, as under the Englislı rule, miglit make litigants more hikely to settle. ${ }^{27}$

It is liardly surprising that comparisons of the two rules to determine which rule minimizes litigation expenditures should be inconclusive, because, as in most economic analyses, exannination of this situation reveals countervailing effects. Compared to the American rule, the English rule increases the reward to successful litigants, but also increases the penalty for unsuccessful litigants by a similar amount. ${ }^{28}$ Given that liti-

23. Shavell, supra note 18 , at 69 .

24. Id. at 69-70.

25. Braeutigam, Owen \& Panzar, supra note 18 , at 182.

26. Another assumption that may limit the general applicability of their conclusions is the assumption that both parties have equal and complete knowledge of the law and facts of the case. Id. at 175.

27. Rowe, Predicting the Effects of Attorney Fee Shifting, supra note 18, at 159. Some of the differences among the analysts' results can be explained by the fact that they were not analyzing precisely the same situations. See infra note 28.

28. Professor Richard Posner, now a judge on the United States Court of Appeals for the Seventh Circuit, has stated categorically that higher stakes will lead to higher expenditures on litigation. See R. Posner, Economic ANALysis of LAw 537-40 (3d ed. 1986). His analysis focuses, however, primarily on the amount of costs incurred once a decision to litigate has been reached. The primary problem in the present case is the crowding of the courts, particularly the Tax Court. Therefore, the primary focus of this analysis is on the decision to litigate, not the decision about how to litigate. Nevertheless, Posner's point-which also plays an important part in the analysis of Braeutigam, Owen \& Panzar, supra note 18, at 180-highlights a source of inefficiency in the English rule. Ineff- 
gants do not know at the outset of litigation whether they will be successful, the incentive and disincentive effects of tlie English rule would seein, a priori, to be in rough equipoise. The English rule might make confident litigants inore inclined to litigate, but might discourage other potential parties whio are not willing at tlie margin to risk tlie increased amount at stake in the litigation. ${ }^{29}$

Althougli it may not be intuitively obvious, the clear effect of using the Englisli rule, instead of the American rule, is to increase each party's stakes by the sum of both parties' litigation costs, not merely by the other party's costs. ${ }^{30}$ Increased stakes might be tliouglit to increase the likelihood that cases will proceed to trial. That argument would proceed as follows. Legal expenses are likely to rise as the stakes rise, but not proportionately-it would cost more to litigate a one million dollar case than a ten thousand dollar case, for example, but probably not one hundred times as much. ${ }^{31}$ As stakes rise, then, the ratio of legal costs to the amount at stake diminishes. When that occurs, relatively small differences in the parties' assessments of their likelihood of success may tip tlie scales in the direction of choosing to litigate the case.

A simple numerical example using the American rule illustrates this point. Suppose Plaintiff has a claim of $\$ 100$ against Defendant. Each party knows that it will cost $\$ 25$ (per litigant) to try tlie claim. Plaintiff believes that he lias a $75 \%$ chance of winning tlie case; Defendant believes that Plaintiff has only a $40 \%$ chance of winning. Under these as-

ciencies are introduced in virtually any situation in which the party who decides how much cost to incur is not responsible to the party who will (or even may) ultimately bear the burden of the costs. Nearly any fee-shifting arrangement-certainly including the shifting induced by the English ruleis subject to this defect to some degree. For further discussion of this point, see infra text following note 39.

29. Shavell's conclusions reflect the position explained in the text: in auto accident cases, the plaintiff's probability of recovery, and hence his confidence, are likely to be lower than they would be in the ultrahazardous activity area, where a strict liability standard would prevail. Shavell, supra note 18 , at $69-70$.

30. This effect can best be illustrated by comparing outcome matrices for the American and English rules, where $\mathrm{J}=$ the amount of the judgment, $\mathrm{Cp}=$ plaintiff's litigation costs, and $\mathrm{Cd}=$ defendant's litigation costs:

\begin{tabular}{|c|c|c|c|}
\hline \multicolumn{4}{|c|}{ American Rule } \\
\hline & (1) Wins & (2) Loses & (3) Stakes $((1)-(2))$ \\
\hline $\begin{array}{l}\text { Plaintiff } \\
\text { Defendant }\end{array}$ & $\begin{array}{c}J-C p \\
-C d\end{array}$ & $\begin{array}{c}-{ }^{-C p} \\
-(J+C d)\end{array}$ & $\mathrm{J}$ \\
\hline \multicolumn{4}{|c|}{ English Rule } \\
\hline & (1) Wins & (2) Loses & (3) Stakes ((1) $-(2))$ \\
\hline $\begin{array}{l}\text { Plaintiff } \\
\text { Defendant }\end{array}$ & $\begin{array}{c}\mathrm{J} \\
-0-\end{array}$ & $\begin{array}{c}-(C p+C d) \\
-(\mathrm{J}+C p+C d)\end{array}$ & $\begin{array}{l}J+C p+C d \\
J+C p+C d\end{array}$ \\
\hline
\end{tabular}

31. See Rowe, Predicting the Effects of Attorney Fee Shifting, supra note 18, at 143 \& n.20 ("[T]he increase in litigation costs is usually not proportional to the rise in the stakes."). 
sumptions, we would expect the case to settle quickly. Plaintiff's expected recovery-the stakes of $\$ 100$ times a .75 probability of success-is $\$ 75$, which, less his $\$ 25$ legal fees, yields a net recovery of $\$ 50$. Defendant's expected loss at trial is $40 \%$ of $\$ 100$, or $\$ 40$, plus litigation expenses of $\$ 25$, for an expected total loss of $\$ 65$. Any settlement between $\$ 50$ and $\$ 65$ will thus leave both parties better off than they expect to be if they try the case.

Assume the same probability assessments apply to a larger caseone in which the damages sought are increased tenfold to $\$ 1000$, and each party's litigation costs are increased fivefold to $\$ 125$ (consistently with the assumption that legal fees mcrease as the stakes do, but not in as high a proportion). Under these circumstances, settlement is unlikely. Plaintiff's expected recovery is $(.75 \times \$ 1000)-\$ 125$, or $\$ 625$. Defendant's expected loss is $(.40 \times \$ 1000)+\$ 125$, or $\$ 525$. There is no longer any settlement figure that can make both parties better off than they expect to be by going to trial because raising the stakes increased the divergence of the estimated final outcomes.32

There is, however, another significant countervaihing effect. As the stakes increase, parties are hikely to expend more resources on prelitigation expenses, such as legal fees and expert reports. These investments are likely to yield better estimates of the probable outcome. And if each party has a more accurate estimate of the probability of the outcome, then the divergence in their estimated final outcomes will be reduced. In the "high stakes" illustration in the preceding paragraph, for example, if Plaintiff ultimately comes to view his probability of winning as $60 \%$, rather than $75 \%$, lie will then value his case at $(.60 \times \$ 1000)-\$ 125$, or $\$ 475$. If Defendant ultimately decides that he has a $50 \%$ chance of losing, rather than a $40 \%$ chance, he will expect the trial to cost him $(.50 \mathrm{x}$ $\$ 1000)+\$ 125$, or $\$ 625$. There is now plenty of room for a settlement, because any transfer between $\$ 475$ and $\$ 625$ will leave both parties better off than they expect to be by litigatimg the dispute.

Whether the improved assessments of outcome probabilities in cases involving higher stakes offset the effect described earlier, by which increased stakes increase the significance of small differences in each

32. This example is introduced primarily to show that increased stakes may lead to increased probabilities of litigation. It also illustrates how the English rule may make it more likely that parties will go to trial. In the first of the two examples in the text, settlement, which was likely under the American rule, becomes unlikely under the English rule. Plaintiff believes his case is worth $.75 \mathrm{x}$ $\$ 100$ (because he will not have his judgment reduced by his costs if he wins) minus $.25 \times \$ 50$ (because he must pay both sides' costs if he loses). This equals $\$ 62.50$. Defendant values the trial at .40 $\mathbf{x}-\$ 150$ (because he pays both parties' costs if he loses). If he wins, he pays nothing because Plaintiff will bear all costs. The expected value of the case to Defendant is thus $-\$ 60$, and he will pay no more than that to settle. Plaintiff will accept no less than $\$ 62.50$. 
party's probability assessinent, is uncertain. In reading tax cases, one is struck by how infrequently large corporations litigate their disputes, even though, as a general inatter, they have the lighest stakes in tax cases. ${ }^{33}$ Higl stakes thus do not appear to lead to a higher probability that a given dispute will lead to litigation. Although this conclusion is unscientific, one is left with the more or less educated guess that increasing the stakes does not inake it more likely that tax disputes will be litigated. Because the primary effect of fee shifting is to increase the stakes, ${ }^{34} \mathrm{im}-$ plementation of a fee-shiftimg rule in the tax area should not increase the number of litigated cases. ${ }^{35}$

The foregoing discussion of the American and English rules sets the stage for an analysis of the actual fee-shifting rules presently applicable in Tax Court litigation. These rules can be characterized as a hybrid of the American and English rules. In most of the cases, the "Tax Court rule" resembles the American rule: the vast majority of litigants bear their own costs, wim or lose. At the extremes, however, there is an important penumbra of the English rule. If the court decides that a taxpayer's case is "frivolous or groundless," "maintained by the taxpayer primarily for delay," or pursued without adequate exhaustion of administrative remedies, damages must be awarded to the government. ${ }^{36}$ Conversely, if the court finds that the government's position in the tax case is not substantially justified, the government may be required to pay the taxpayer's

33. Thus, the settlement rate in disputes that reach the appellate level is about the same for large cases having an asserted deficiency of over one million dollars as it is for other cases. In 1984, $81.5 \%$ of such large cases were settled. The overall settlement rate in that year was $83 \%$. See 1984 IRS ANN. REP. 35.

34. See supra notes 30-32 and accompanying text.

A one-way fee-shifting scheme, where only one side can obtain its attorney fees if it prevails, would also raise the stakes. All other factors held constant, however, one-way fee shifting does not increase the stakes as drastically as two-way fee shifting. The table below illustrates a one-way scheme favoring plaintiffs.

\begin{tabular}{lccc} 
& \multicolumn{2}{c}{ One-Way Fee Shifting } \\
& $\frac{\text { (1) Wins }}{J}$ & $\frac{(2) \text { Loses }}{-C p}$ & $\frac{\text { (3) Stakes ((1)-(2)) }}{J+C p}$ \\
Plaintiff & $-C d$ & $-(J+C p+C d)$ & $J+C p$
\end{tabular}

Thus, the stakes are the amount in controversy plus the plaintiff's litigation costs. Cf. supra note 30 (illustrating that stakes under the American rule are the amount in controversy, and stakes under the English rule are the amount in controversy plus both parties' litigation costs).

35. Discussion of the impact of willingness to bear risks on the decision to litigate has been omitted, largely in the interest of simplicity. One would expect, however, that risk-averse parties would be less likely to litigate in the face of rules that increase litigation stakes. If there are many risk-averse taxpayers and few risk-preferring taxpayers, the English rule should dampen inclinations to litigate. See Rowe, Predicting the Effects of Attorney Fee Shifting, supra note 18, at 159.

36. I.R.C. $\S 6673$ (1982), as amended by Tax Reform Act of 1986, Pub. L. No. 99-514, $\S 1552(a), 100$ Stat. $2085,2753$. 
reasonable litigation costs. ${ }^{37}$

As noted before, this pair of statutory provisions is asymmetrical in a number of respects. ${ }^{38}$ Nonetheless, the provisions threaten each party with the prospect of damages if its position is unjustified under the law or on the facts of the particular case. The provisions together produce an attractive arrangement, capturing the best elements of the English rule, while avoiding aspects of that rule that might be more problematic. For example, one miglit be concerned about the effects of the English rule on risk-averse parties who believe that they have a reasonable, but not overwhelming, chance of success. The risk of having to bear botli parties' litigation costs may inhibit a potential litigant from prosecuting a claim if his initial presentation to an adverse party is rebuffed. In contrast, the chilling effects of sections 6673 and 7430 are weaker because a reasonable case, even if unsuccessful, will not expose the litigant presenting that case to liability for his opponent's fees. Sections 6673 and 7430 only discourage those potential litigants witli unreasonable cases, and perhaps those who are pathologically timid. Discouraging the former group-which is presumably mucl larger than the latter group-is, of course, the intended goal of those sections.

Anotlier aspect of the Englisli rule that may be troublesome is that parties liave less incentive to inake efficient decisions about the size of their litigation costs, because there is typically a good chance that they will not have to bear tlie burden of those costs. ${ }^{39}$ Again, however, the fact tliat sections 6673 and 7430 operate only in extreme cases makes this problein de minimis. In the great inajority of cases, the probability of recovering costs under those sections is reinote. Occasionally, a party (or Inore likely the party's attorney) may sense that lis adversary is embarking on a course that is so unreasonable that it may expose the adversary to fee-slifting penalties. A party who perceives that his opponent's position is unreasonable, however, is unlikely to incur extra litigation costs because tlie incremental litigation costs will have little effect on the substantive outcome (which by assumption appears to the attorney to be a foregone conclusion). In addition, given the difficulty of proving that an opponent's position is not merely wrong but also frivolous or lacking substantial justification, a significant risk exists that the prevailing party will bear tliose incremental costs, even if the underlying dispute is won. By operating only at the extremes, sections 6673 and 7430 are nearly

37. Id. § 7430 (1982 \& Supp. I1I 1985), as amended by Tax Reform Act of 1986, Pub. L. No. 99-514, § 1551, 100 Stat. 2085, 2752-53.

38. See supra notes 10-17 and accompanying text.

39. See supra note 28. 
immune to this variant of the "moral hazard" problem of a litigant not being responsible for the costs of his own actions.

While avoiding these drawbacks, sections 6673 and 7430 incorporate the penalty that the Enghish rule imposes on litigants who bring weak cases or present weak defenses. A hitigant who forces another into court without good grounds has imposed costs on the adverse party that, under a pure American rule, would not be borne by the party taking the unreasonable position. Forcing unreasonable hitigants to bear the costs of their actions is an important goal that sections 6673 and 7430 further.

That conclusion is unaffected when it is the government-and hence the public generally-that is exposed to possible liability for litigating without substantial justification. When a choice must be made between imposing costs on an innocent victim of governmental unreasonableness or imposing costs on the public at large, it seems more equitable and more efficient to impose the cost on the government. ${ }^{40}$ Furthermore, democratic and budgetary processes provide some accountability, albeit imperfect. There is some hope that those who make unreasonable decisions on behalf of the government (or perhaps those who supervise governmental systems under which unreasonable decisions are made) will ultimately bear the costs of those actions.

In conclusion, by searching for an answer to the positive question (Which rule-Enghish or American-minimizes litigation costs?), we have also come across at least a partial answer to the normative question (Which is the better rule?). First, the current hybrid rule is preferable to the American rule. To put this conclusion in terms of the countervailing effects identified earlier, one can say that the hybrid rule operates to discourage the most inefficient uses of the tax litigation machinery, those in which the tax dispute is a spurious one, maintained primarily by a stubborn and unreasonable party. Such cases add little to the body of significant case-law precedent, while consuming substantial judicial resources. As to the more useful tax cases-those in which the taxpayer and the government may reasonably differ in their interpretations of the law or facts-the hybrid rule produces the same result as the American rule.

It is not possible, on the basis of the foregoing arguments, to reject conclusively the possibility that adoption of the English rule in tax cases would produce still more efficient litigation decisions. Even so, when compared with the English rule, the hybrid rule seems attractive in important respects. The hybrid rule preserves the primary advantage of the English rule by preventing unreasonable litigants from imposing costs on

40. The government is in a better position to bear these costs and to spread risk than is the victimized taxpayer. 
reasonable ones. In close cases, however, where there is no unreasonable litigant, the advantages of the English rule are less clear. In such cases, it seems inappropriate to view either party as imposing costs on the other; the costs borne initially by each hitigant are perhaps better viewed as the costs of their mutual participation in a complex economic world-a world in which they may each have reasonable, yet contradictory, interpretations of a law or an event. An all-or-nothing assessinent of litigation costs in such circumstances, as the English rule would require, has a lottery-like quality. Although not clearly inefficient, ${ }^{41}$ that result seems less appeahing than the result under the American rule or the hybrid rule, under which the respective parties would bear their own costs. ${ }^{42}$ Thus, though the argument is less compelling as to the English rule, there are sound reasons for concluding that the hybrid rule is indeed preferable to either the American or Enghish rules.

\section{Amendments to the IRC FEe-Shifting Rules UNDER the TAX REFORM ACT OF 1986}

In the Tax Reform Act of 1986, Congress made four major changes to section 7430 of the IRC. These changes generally apply to amounts paid to taxpayers after September 30,1986, in actions commenced after December 31, 1985.43

The first change alters the standard by which the government's position is to be evaluated. The former provisions of section 7430 focused on whether the government's position was reasonable, whereas the new provision focuses on whether the government's position was "substantially justified." 44 Second, the evaluation of whether the government's position was substantially justified now explicitly includes review of the final administrative position taken by the IRS. The former provisions of section 7430 refer only to the government's "position . . . in the civil proceeding." 45 Third, the maximum award for attorney fees has been set at $\$ 75$ per hour, and reimbursement of costs for expert testimony and prepara-

41. For example, there are surely some efficiency-enhancing effects in rules that, like the English rule, reward those who make good predictions about the outcomes of close cases. An ultimate judgment on such rules is dependent on assumptions about how well courts decide close cases. This issue is clearly beyond the scope of this article.

42. Of course, in close cases, the decision itself has a lottery-like quality that is troublesome; nevertheless, it is preferable not to add litigation costs to the stakes of that lottery.

43. Tax Reform Act of 1986, Pub. L. No. 99-514, § 1551(h), 100 Stat. 2085, 2753.

44. I.R.C. $\$ 7430$ (c)(2)(A)(i) (1982), as amended by Tax Reform Act of 1986, Pub. L. No. 99 514, § 1551(d)(1), 100 Stat. 2085, 2752. See supra note 15 and accompanying text.

45. I.R.C. $\$ 7430($ c)(2)(A)(i) (1982), as amended by Tax Reform Act of 1986, Pub. L. No. 99 $514, \S 1551$ (e), 100 Stat. 2085, 2753. Courts are not uniform in their interpretation of this provision. See infra note 86 and accompanying text. 
tion of expert reports, tests, and the like, must be based on prevailing market rates, which, in the case of expert witnesses, may not exceed the then-current government rate for sucli services. ${ }^{46}$ The former maximum was specified in terms of the total costs of the litigation and was fixed at $\$ 25,000.47$ Finally, Congress has imposed net worth limitations on the parties who are eligible for fee reimbursements, permitting reimbursements only to individual taxpayers having a net wortli of less than $\$ 2,000,000$ and to entities having a net worth of less than $\$ 7,000,000.48$ The former provision did not impose sucl1 limitations.

The Senate Finance Committee added all but the last of these changes to the House bill. ${ }^{49}$ The Senate Finance Committee's primary goal was to conform the fee-reimbursement provisions applicable to tax cases to the counterpart provisions contained in the Civil Rights Attorney's Fees Awards Act of 1976 (CRAFAA) ${ }^{50}$ and in the Equal Access to Justice Act of 1980 (EAJA). ${ }^{51}$ A further change moving in that direction-a shift in the burden of proof from the taxpayer to the government in section 7430 cases-was passed by the Senate but deleted by the House-Senate Conference Committee formed to consider this bill. ${ }^{.2} \mathrm{Be}-$ cause the Senate may seek furtlier conformance of section 7430 to the CRAFAA and the EAJA, this proposed change, though not enacted, is discussed below in detail, as are the changes that have already been adopted.

46. I.R.C. $\$ 7430$ (c)(1)(A)(ii)(I) (1982), as amended by Tax Reform Act of 1986, Pub. L. No. 99-514, § 1551(c), 100 Stat. 2085, 2752.

47. Id. $\S 7430(b)(1)$ (1982), repealed by Tax Reform Act of 1986, Pub. L. No. 99-514, $\S 1551($ a), 100 Stat. 2085, 2752.

48. Tax Reform Act of 1986, Pub. L. No. 99-514, §1551(d)(2), 100 Stat. 2085, 2752-53 (to be codified at $\S 7430(\mathrm{c})(2)(\mathrm{A})(\mathrm{iii}))$. This provision incorporates the definition of "party" contained in 5 U.S.C.A. $\$ 504(b)(1)(B)$ (West Supp. 1986), which provides as follows:

"[P]arty" means a party, as defined in section 551(3) of this title, who is (i) an individual whose net worth did not exceed $\$ 2,000,000$ at the time the adversary adjudication was initiated, or (ii) any owner of an unincorporated business, or any partnership, corporation, association, unit of local government, or organization, the net worth of which did not exceed $\$ 7,000,000$ at the time the adversary adjudication was initiated, and which had not more than 500 employees at the time the adversary adjudication was initiated; except that an organization described in section 501(c)(3) of the Internal Revenue Code of 1954 (26 U.S.C. 501(c)(3)) exempt from taxation under section 501(a) of such Code, or a cooperative association, as defined in section 15(a) of the Agricultural Marketing Act (12 U.S.C. $1141 \mathrm{j}(\mathrm{a}))$, may be a party regardless of the net worth of such organization or cooperative association.

49. See H.R. CONF. REP. No. 841, 99th Cong., 2d Sess. 800-02 (1986) [hereinafter CONFERENCE REPORT]; S. REP. No. 313, 99th Cong., 2d Sess. $197-99$ (1986).

50. Pub. L. No. 94-559, § 2, 90 Stat. 2641 (codified at 42 U.S.C. $\S 1988$ (1982)). See CoNFERENCE REPORT, supra note 49, at 799.

51. Pub. L. No. $96-481, \S 204(a), 94$ Stat. $2325,2327-29$ (codified at 28 U.S.C. $\S 2412$ (b) (1982)); see CONFERENCE REPORT, supra note 49, at 799-801.

52. See CONFERENCE REPORT, supra note 49 , at 800-02. 


\section{A. The "Substantial Justification" and "Reasonableness" Standards.}

Prior to the 1986 amendments, in order to be eligible for reimbursement of fees under section 7430, a taxpayer had to establish that the government's position was unreasonable. ${ }^{53}$ In contrast, under the amended provisions, the taxpayer must show only that the government's position was not "substantially justified." 54 One might assume that there is httle difference between the two standards. After all, each phrase can be defined in terms of the other: a reasonable position is one that is substantially justified; a substantially justified position is a reasonable one. In Washington v. Heckler, ${ }^{55}$ the United States Court of Appeals for the Third Circuit held that to prove substantial justification in the context of the EAJA, which has used that phrase since its inception, ${ }^{56}$ the government must show the following: "(1) a reasonable basis in truth for the facts alleged; (2) a reasonable basis in law for the theory it propounds; and (3) a reasonable connection between the facts alleged and the legal theory advanced." 57 Similarly, the legislative history of the EAJA employs the notion of reasonableness to explain the "substantially justified" standard: "The test of whether or not a Government action is substantially justified is essentially one of reasonableness." 58

Despite these similarities, there may be a small difference in meaning between the two terms. There may be cases in which it would be reasonable to proceed with a position that has some justification, though that justification might not rise to a level where it could be said to be substantial. In Washington, the Third Circuit hinted at such a possibility: "The government's burden of showing substantial justification is a strong one and is not met merely because the government adduces 'some evidence' in support of its position." 59 Moreover, in the committee reports accompanying the recent EAJA amendments, ${ }^{60}$ Congress criticized

53. See supra text accompanying note 44.

54. I.R.C. $\S 7430$ (c)(2)(A)(i) (1982), as amended by Tax Reform Act of 1986, Pub. L. No. 99 514, §1551(d)(1), 100 Stat. 2085, 2752.

55. 756 F.2d 959 (3d Cir. 1985).

56. See 28 U.S.C. $\$ 2412$ (d)(1)(A) (1982).

57. Washington, 756 F.2d at 961 (emphasis added).

58. H.R. REP. No. 1418, 96th Cong., 2 d Sess. 10, reprinted in 1980 U.S. CODE CONG. \& ADMIN. NEWS 4984, 4989. But see infra note 61 and accompanying text.

59. Washington, 756 F.2d at 961 . The notion that the government might have a "strong" burden under the EAJA is disturbing, and may call into question the argument that the burden of proof in IRC fee-shifting cases is unimportant. See infra notes 102-18 and accompanying text. If "preponderance of the evidence" is the standard, as it should be, then assignment of the burden would usually be inconsequential; if the standard in effect requires "clear and convincing" evidence, then assignment of the burden would obviously be more important.

60. H.R. REP. No. 120, 99th Cong., 1st Sess., pt. 1, at 9-10, reprinted in 1985 U.S. CODE CONG. \& ADMIN. NEWS 132, 137-39. 
those courts that have failed to require the government to meet a standard of justification for its position that was higher than mere reasonableness. For example, the Ways and Means Committee report stated:

Several courts have held correctly that "substantial justification" means more than merely reasonable....

[We are puzzled, however, by] statements by some courts that an administrative decision may be substantially justified under the Act even if it must be reversed because it was arbitrary and capricious or was not supported by substantial evidence. Agency action found to be arbitrary and capricious or unsupported by substantial evidence is virtually certain not to have been substantially justified under the Act. ${ }^{61}$

At least as applied to tax cases, this approach may impose an excessive burden on the government.62 In particular, the Ways and Means Committee's suggestion that a fee award should be "virtually certain" when an agency action is found to be "arbitrary and capricious" would produce unsound results in a number of tax cases. This may seem odd; one would thimk that an arbitrary and capricious action would be highly unreasonable. Nonetheless, the juridical meaning of "arbitrary and capricious" has evolved over time and today barely resembles the ordinary meaning of that phrase. ${ }^{63}$

The case law under IRC section $482^{64}$ provides an example of this

61. Id. at 9, reprinted in 1985 U.S. CODE CONG. \& ADMIN. NEwS at 138 (footnote omitted).

62. This approach would also impose excessive liability on the government in federal cases generally. The federal courts often will hold that an agency acted "arbitrarily and capriciously" if that showing is necessary to find against the government.

One commentator has argued that it would be "absurd" to find that the government had satisfied the EAJA's substantial justification test where an agency's action has been found "arbitrary and capricious." Note, Reenacting the Equal Access to Justice Act: A Proposal for Automatic Attorney's Fee Awards, 94 YALE L.J. 1207, 1217 (1985). This view ignores the fact that the "arbitrary and capricious" talisman no longer retains its natural meaning. See infra note 63 and accompanying text.

The commentator also argues that the EAJA's substantial justification standard should be replaced with automatic fee shifting. Note, supra, at 1221-28. Automatic fee shifting would be extremely costly and would tend to dampen the government's enforcement activities, particularly in developing areas of the law.

63. See, e.g., 5 K. Davis, Administrative Law Treatise $\$ \S 29: 6-29: 7$ (2d ed. 1984) (discussing judicial interpretations of the "arbitrary and capricious" standard); R. PIERCE, S. SHAPIRo \& P. VerkuIL, ADMINISTRATIVE LAW AND PROCESS $\S 7.3 .2$ (1985) (contrasting early, deferential judicial interpretation of agency action under "arbitrary and capricious" standard with today's far more "searching and careful" imquiry).

64. Section 482 provides:

In any case of two or more organizations, trades, or businesses (whether or not incorporated, whether or not organized in the United States, and whether or not affiliated) owned or controlled directly or indirectly by the same interests, the Secretary may distribute, apportion, or allocate gross income, deductions, credits, or allowances between or among such organizations, trades, or businesses, if he determines that such distribution, apportionment, or allocation is necessary in order to prevent evasion of taxes or clearly to refiect the income of any of such organizations, trades, or businesses.

I.R.C. $\S 482$ (1982). 
phenomenon. Section 482 gives the IRS broad discretion to allocate items of income and expense among related entities when necessary to prevent tax evasion. The IRS invokes this provision to combat, among other things, arrangements between domestic corporations and their foreign subsidiaries in which the parent loans money, rents buildings, or provides other goods and services to the subsidiary at below-market rates $\mathrm{m}$ order to create the appearance of relatively high expenses at the parent level, and relatively low expenses (and, hence, high profits) at the subsidiary level. Absent IRS reallocation of income and expense items, the domestic corporation would obtain a substantial tax deferral because United States taxes on the subsidiary's profits would ordinarily not be imposed until the subsidiary's profits were distributed to the parent through dividends. ${ }^{65}$

Because the IRS has broad discretion under section 482, a court may adjust or disregard the government's reallocations in section 482 cases only if it finds that the IRS acted arbitrarily and capriciously. ${ }^{66}$ Thus, each time a court rejects the IRS's section 482 reallocations, it is necessarily finding the action to be arbitrary and capricious. ${ }^{67}$ Routinely awarding fees to victims of "arbitrary and capricious" actions by the IRS would allow virtually every taxpayer who won a section 482 case to recover his fees. ${ }^{68}$ That outcome could not be what Congress had in mind. 69

65. See id. § 951(a)(2)(A).

66. See, e.g., Liberty Loan Corp. v. United States, 498 F.2d 225, 229 (8th Cir.), cert. denied, 419 U.S. 1089 (1974); Ballentine Motor Co. v. Commissioner, 321 F.2d 796, 800 (4th Cir. 1963); Grenada Indus. v. Commissioner, 17 T.C. 231, 255 (1951), aff'd, 202 F.2d 873 (5th Cir.), cert. denied, 346 U.S. 819 (1953).

67. There are literally scores of cases in which courts have found the government's section 482 reallocations "arbitrary and capricious." See, e.g., Heaton v. United States, 573 F. Supp. 12, 14 (E.D. Wash. 1983); Nissho Iwai Am. Corp. v. Commissioner, 50 T.C.M. (CCH) 1483, 1495-98 (1985); Hospital Corp. of Am. v. Commissioner, 81 T.C. 520, 595 (1983); Pacella v. Commissioner, 78 T.C. 604, 621 (1982); Morrison v. Commissioner, 44 T.C.M. (CCH) 1459, 1471 (1982); Keller v. Commissioner, 77 T.C. 1014, 1025 (1981), aff'd, 723 F.2d 58 (10th Cir. 1983); Achiro v. Commissioner, 77 T.C. 881,900 (1981).

68. A court can refuse to award costs if it believes an award is inappropriate, as perhaps it would in closely contested section 482 cases. Section 7430 provides only that costs "may be awarded" to the prevailing party. I.R.C. $§ 7430$ (a) (1982) (emphasis added). The EAJA is slightly more explicit on this point, providing that fees shall be awarded unless "special circumstances make an award unjust." 28 U.S.C. § 2412(d)(1)(A) (1982 \& Supp. III 1985). One can certainly understand, however, that the government would prefer not to leave this question entirely to the discretion of the judge. It is far from clear, after all, that a judge would view awarding fees in cases of this sort as "inappropriate or unjust."

69. We know Congress did not mcan this to be the case in the EAJA, because it said so flatly: "The [substantial justification] standard, however, should not be read to raise a presumption that the Government position was not substantially justified, simply because it lost the case." H.R. REP. No. 1418, 96th Cong., 2d Sess. 11, reprinted in 1980 U.S. CODE CONG. \& ADMIN. NEws 4984, 4990. 
Even in situations where the government is granted less discretion than it has in section 482 cases, raising the standard of reasonableness may hinder the government's ability to enforce the IRC. ${ }^{70}$ The government is entitled to mamtain an adversarial posture in its litigating positions. If it has a reasonable basis for its position, it should not have to worry about whether its justification would, in the harsh light of hindsight, rise to a level of substantiality.

A chilling effect on the IRS's enforcement efforts could be particularly damaging in cases $m$ which the IRS believes that a taxpayer is manipulating a characterization question to his advantage. For example, the taxpayer may have documents that purport to obligate him to pay "interest," and he may then deduct those payments. The IRS may believe that the transaction as a whole does not create a true debt. ${ }^{71}$ If the IRS wins, there will of course be no problem. If, on the other hand, the court finds that the interest payments were bona fide, the IRS may have some difficulty pointing to the concrete autlority that gave it substantial justification for its position. Existing precedent on sliam transactions could help, but the ingenuity of taxpayers in developing unprecedented miscliaracterizations may make it difficult to cite prior cases liaving sufficient factual similarity. Such an outcome would be unfortunate.

Although the committee reports to the Tax Reform Act of 1986 contain little direct guidance on how to apply the "substantially justified" standard in tax cases, they do provide some indirect guidance in the form of cross-references to the EAJA. ${ }^{72}$ The committee reports do not cite the language quoted above from the EAJA amendments' legislative history ${ }^{73}$ (regarding the virtual necessity of fee reimbursements when the government is found to liave acted arbitrarily and capriciously), but those reports do say that the purpose of the amendments is "to conform [section 7430] more closely to the Equal Access to Justice Act."74 It is appropriate, therefore, to assume that what Congress said regarding the EAJA provisions applies witl equal force to identical provisions in section 7430 .

This statement is somewhat inconsistent with the view expressed in the committee reports to the 1985 EAJA amendments. See supra notes 60-61 and accompanying text.

70. Cf. H.R. REP. No. 1418, 96th Cong., 2d Sess. 10, 13-14, reprinted in 1980 U.S. CODE CONG. \& ADMIN. NEws 4984, 4992 (noting possible chilling effect of proposed mandatory EAJA awards on the government's enforcement activities).

71. See, e.g., Knetsch v. United States, 364 U.S. 361, 364-66 (1960) (leveraged purchase of annuity savings bonds did not result in "indebtedness" within meaning of IRC).

72. See CONFERENCE RePORT, supra note 49, at 799-802.

73. See supra notes 60-61 and accompanying text.

74. See CONFERENCE RePort, supra note 49 , at 801 . 
Reliance on the EAJA is unfortunate in two respects. First, as argued above, the EAJA may set an inappropriately high standard for the government in many tax cases. Second, the EAJA's guidance is incomplete, in that it fails to advise courts on how to apply the standard in certain situations that arise uniquely in tax disputes. For example, can the IRS hedge its bets by taking opposite sides of an issue with respect to two taxpayers? This situation might arise, for instance, when an employer transfers valuable property to an employee upon the employee's retirement. The employee says that the transfer was a gift, which is excludable from his return, ${ }^{75}$ but is largely nondeductible by the einployer. ${ }^{76}$ The employer maintains that the transfer was compensatory, which makes it fully deductible for him, but income for the employee. Is the IRS "substantially justified" in disallowing the deduction on the employer's return and requiring inclusion on the employee's return, even though those positions are contradictory? ${ }^{77}$

Presumably, if the case is closely balanced, the government will be able to show, even as to the case that it loses, that its position was nevertheless substantially justified. But consider the following hypothetical situation. Everyone (the government, the taxpayers, and ultimately the Tax Court) agrees that either $A$ or $B$ should be taxed on a substantial amount of income generated by a transaction in which $A$ and $B$ jointly participated. Neither $A$ nor $B$ reported the incone. The government believes that the probability that it will prevail against $A$ on this issue is eighty percent, and that the probability of prevailing against $B$ is only twenty percent. Further, the government believes that the issue is such that losing to either taxpayer virtually guarantees winning against the other. Following the odds, the government proceeds first against $A$. It knows, however, that before it can obtain a judgment in the Tax Court against $A$, the limitations period for the relevant tax year will have ex-

75. See I.R.C. $\S 102$ (a) (1982) (amended 1986). After 1986, section 122(b) of the Tax Reform Act of 1986 will prevent the problem identified in the text from arising; I.R.C. $\S 102$ (c), as amended, disallows exclusion from income of gifts from employers. See Tax Reform Act of 1986, Pub. L. No. 99-514, § 122(b), 100 Stat. 2085, 2110 (to be codified at I.R.C. $\S 102(c)(1)$ ).

76. Id. $\S 274(\mathrm{~b})(1)(1982)$ (generally allowing employer to deduct the cost of a gift to employee only to the extent that the cost of all gifts that year to that employee does not exceed $\$ 25$; in somc cases a $\$ 400$ limit applies).

77. The government took inconsistent positions in two cases involving the same employer gift, and lost both. Compare Estate of Carter v. Commissioner, 453 F.2d 61, 64-70 (2d Cir. 1971) (payments to widow of deceased partner were gifts rather than income as alleged by IRS) with Bank of Palm Beach \& Trust Co. v. United States, 476 F.2d 1343, 1346-51 (Ct. Cl. 1973) (payments to widow of deceased partner were deductible business expenses because they were additional compensation for services previously rendered and served to increase morale of employees in general). 
pired for $B .{ }^{78}$ Because additional tax can legitimately be collected from one of these two taxpayers, protection of the fisc would seem to require that the government file an assessment agamst $B$ to offset the risk that it will lose its case against $A$. Suppose that the government files an assessment against $B$ to prevent the expiration of the limitations period and then wims its case agamst $A$, after which it promptly drops its assessment against $B$. If $B$ seeks reimbursement of his costs, will the government be able to meet the substantial justification standard given that the government believed that it only had a twenty percent chance to prevail against $B ?^{79}$ This question takes on added significance in hight of another section 7430 amendment added by the Tax Reform Act of 1986: the new requirement that the court examine the administrative position of the government in evaluating whether its position was substantially justified. ${ }^{80}$ Before this change, there was at least some chance that the government's immediate dismissal of the case against $B$, after having won its case against $A$, could have precluded $B$ 's recovery of costs. ${ }^{81}$

Another example of the incomplete guidance that the "substantial justification" standard provides is when the IRS zealously enforces a court-made rule that it dislikes, primarily to bring a new case before the court so that the court can reverse its earher decision. ${ }^{82}$ What if there is an internal IRS memo stating that the court's initial position, and hence the government's position in the new case, is unreasonable? As in the case where the government proceeds against two taxpayers, knowing that only one owes additional tax, the government may be acting reasonably as to the whole problem, but may have difficulty showing that its assessment against a particular taxpayer was substantially justified. ${ }^{83}$ Guidance from Congress on questions of this sort would have been useful to

78. The usual limitations period on assessments of tax extends three years from the date the return was filed. See I.R.C. \$ 6501(a) (1982).

79. One is not completely without sympathy for $B$ in this case, since he does indeed seem, under the assumptions of the hypothetical, to have reported his income accurately. Nevertheless, the costs to $B$ in most cases will not be great: typically, he would simply be asked to waive the statute of limitations, and his case would be held in abeyance pending the outcome in the case against $A$. In any event, it would not seem that $B$ 's costs result from any unjustified or unreasonable governmental actions. They are simply a cost of compliance with a complex tax system.

80. See supra notes $43-52$ and accompanying text.

81. But see infra note 86 and accompanying text.

82. This appears to have been the government's approach in Commissioner v. Boylston Mkt. Ass'n, 131 F.2d 966, 967-68 (1st Cir. 1942) (IRS changed its position to conform to a court's ruling that a cash-basis taxpayer may deduct three-year prepayments of insurance premiums as an ordinary and necessary business expense in the year payment was made). The situations in which the government would be in a position to engage in this kind of action are probably rare.

83. It should be noted that both of the areas of uncertainty identified in the text were present under the reasonableness standard as well as the substantial justification standard. To the extent that the latter is intended to be a higher standard, however, they become more problematic. 
the courts. More importantly, it would have given the IRS some clearer signals on what litigation behavior is sanctioned.

\section{B. Consideration of the Government's Administrative Position in Addition to its Litigation Position.}

Under the EAJA, a court awarding costs to a successful litigant may scrutinize the position taken by the government prior to litigation, as well as its position as expressed in court. ${ }^{84}$ Before it was amended by the Tax Reform Act of 1986, IRC section 7430, in contrast, focused attention solely on the government's position "in the civil proceeding," an obvious reference to the substantive tax case in federal court. ${ }^{85}$ Despite the specific language just quoted, some courts lield that the relevant "position," for purposes of section 7430 cases arising before the effective date of the 1986 amendments, mcluded the prehitigation position of the IRS.86 In the recent amendments, Congress resolved this issue by conforming section 7430 to the EAJA on this poimt. The new rule makes it clear that the "position of the United States" includes "any administrative action or inaction by the District Counsel of the Internal Revenue Service (and all subsequent administrative action or inaction)." 87

It is easy to identify the impetus for this change. In many cases, taxpayers will mcur great expense in dealmg with an unjustified IRS position durmg the administrative proceeding, only to have the government concede the case just before trial. ${ }^{88}$ In one sense, this argument proves

84. 28 U.S.C. $\$ 2412$ (d)(2)(D) (Supp. III 1985). Compare Keasler v. United States, 766 F.2d 1227, 1231 (8th Cir. 1985) ("position of the United States" includes both the prelitigation position and the litigation position) and Natural Resources Defense Council, Inc. v. EPA, 703 F.2d 700, 70612 (3d Cir. 1983) (same) with Russell v. National Mediation Bd., 764 F.2d 341, 349-52 (5th Cir. 1985) (only government's litigation position is analyzed under EAJA) and Morris Mechanical Enters. v. United States, 728 F.2d 497, 498-99 (Fed. Cir.) (same), cert. denied, 469 U.S. 1033 (1984).

85. The quoted phrase is from I.R.C. $\$ 7430$ (c)(2)(A)(i) (1982) (amended 1986). The operative rule of section 7430, expressed in subsection (a), refers to recovery of costs in civil proceedings in federal courts. Subsection (c) provides definitions for use in section 7430 .

86. See, e.g., Powell v. Commissioner, 791 F.2d 385, 388-92 (5th Cir. 1986); Kaufman v. Egger, 758 F.2d 1, 3-4 (1st Cir. 1985); Finney v. Roddy, 617 F. Supp. 997, 1001-02 (E.D. Va. 1985); Sharpe v. United States, 607 F. Supp. 4, 7-8 (E.D. Va. 1984); Hallam v. Murphy, 586 F. Supp. 1, 3 (N.D. Ga. 1983).

Other courts have held that only the position of the United States during the litigation stage should be considered. See, e.g., Ewing \& Thomas v. Heye, 803 F.2d 613, 615 (11 th Cir. 1986); Baker v. Commissioner, 787 F.2d 637, $641-42$ (D.C. Cir. 1986); United States v. Balanced Fin. Management, Inc., 769 F.2d 1440, 1450 (10th Cir. 1985).

87. Tax Reform Act of 1986, Pub. L. No. 99-514, $\S 1551$ (e), 100 Stat. 2085, 2753 (to be codified at I.R.C. $\$ 7430(c)(4))$.

88. See Note, supra note 62 , at 1215-16. The government's action prior to the litigation could also be shielded from scrutiny if the government changes its position when a case reaches litigation. Id.; see also Natural Resources Defense Council, 703 F.2d at 706-07 (failure to consider the government's prelitigation position would mean "that no matter how outrageously improper the agency 
too much: the argument works equally well to justify allowing the taxpayer to recover costs at even earher stages of a tax controversy. Taking a tax case through the internal IRS appeals process can be exhausting and costly, and-if there is no substantial justification for the IRS position-a good case for cost reimbursement can be made. In fact, every taxpayer who is audited, but against whom little or no additional tax is assessed, arguably deserves compensation for his trouble and his out-ofpocket costs; the taxpayer is the unfortunate one-in-fifty who was cliosen for the rigors of an audit, typically without any ex ante evidence that a deficiency will be found.

Congress, of course, has not enacted any such general administrative costs reimburseinent provision, apparently believing that a modest ainount of inconvenience and cost is soinething that taxpayers reasonably can be asked to bear. Our point is simply that there is no principled basis on which to draw a precise line dividing deserving fee-reimbursement cases from undeserving ones. As a controversy moves through the adininistrative, pretrial, and trial phases, taxpayer costs continue to grow, and the government becomes inore and more culpable for defects in its case. There is nothing special, at least in teruns of fairness to taxpayers, about any particular phase in the process.

There is a practical basis on which to draw a line, however, because the new rule does affect tlie use of judicial resources. Under the rule that confined consideration to the government's litigating position, the court deciding a fee issue would also liave heard the underlying substantive tax case. Expanding consideration to include the prelitigation position requires the court to inake an inquiry into facts not otherwise before it. This is particularly true wliere tlie government concedes inımediately after the taxpayer files an action. In that situation, the court, which would not otherwise liave devoted any attention at all to the case, nust review both the facts and the law to determine whether cost reimbursement is appropriate. In light of the current backlog of tax cases, ${ }^{89}$ a problem likely to worsen as increasing numbers of complicated tax shelter cases are tried, this judicial economy argunent is compelling. Unfortunately, Congress either ignored this point or found it insufficiently weighty.

action has been, and no matter how intransigently a wrong position has been maintained prior to the litigation, and no matter how often the same agency repeats the offending conduct, the statute has no application, so long as employees of the Justice Department act reasonably when they appear before the court").

89. In the Tax Court alone, there were 77,491 cases pending as of September 30, 1985. 1985 IRS ANN. REP. 39. 


\section{Maximum Reimbursements.}

Prior to its amendment by the Tax Reform Act of 1986, section 7430 (b)(1) of the IRC imposed an overall cap of $\$ 25,000$ on the litigation expenses that could be awarded to any one party in any action, but it contained no other limitations on the amount of reimbursement. ${ }^{90}$ The EAJA, im contrast, has no cap on aggregate expenses, but limits recovery for legal fees to no more than $\$ 75$ per hour for each lawyer's time. ${ }^{91}$ In addition, the EAJA allows recovery of reasonable expenses for expert witnesses and for preparation of expert studies and reports. Again, the 1986 amendments conformed section 7430 to these EAJA provisions. ${ }^{92}$

The first thing any tax practitioner is likely to note about these provisions is that the $\$ 75$ per hour maximum award for attorney fees is wholly unrealistic, at least if it is seriously intended to cover the full costs of hiring an experienced tax lawyer. In many firms in large cities, the lowest billing rate for any lawyer in the firm approaches or exceeds the statutory maximum, and that lowest rate would apply only to the time of new associates, to whom primary responsibility for a complex tax dispute would never be entrusted. ${ }^{93}$ A more realistic amount in most cities for a lawyer qualified to hitigate a case in the Tax Court would be $\$ 125$ to $\$ 150$ per hour. ${ }^{94}$

90. I.R.C. $\$ 7430(b)(1)$ (1982), repealed by Tax Reform Act of 1986, Pub. L. No. 99-514, $\S 1551$ (a), 100 Stat. 2085, 2752.

91. 28 U.S.C. $\$ 2412$ (d)(2)(A) (1982 \& Supp. III 1985).

92. Tax Reform Act of 1986, Pub. L. No. 99-514, $\S 1551$ (a), 100 Stat. 2085, 2752 (repealing the $\$ 25,000$ cap); id. \$ 1551(c) (amending section 7430(c)(1) to qualify "reasonable expenses," "costs," and "fees" as based on "prevailing market rates").

93. Darby, Are You Keeping Up Financially?, A.B.A. J., Dec. 1985, at 66, reports the following survey data on 1985 billing rates for lawyers at various stages of their careers:

$\begin{array}{lr}\text { Senior partner } & \$ 141 / \mathrm{hr} . \\ \text { Middle partner } & 121 / \mathrm{hr} . \\ \text { Younger partner } & 104 / \mathrm{hr} . \\ \text { Senior associate } & 90 / \mathrm{hr} . \\ \text { Middle associate } & 79 / \mathrm{hr} . \\ \text { Younger associate } & 67 / \mathrm{hr} .\end{array}$

Id. at 66.

94. In an effort to be more specific than the survey data in the preceding note permits (though admittedly less scientific), the authors tried to describe what the youngest lawyer who would be indisputably well qualified to try a complex tax case would look like. The attorney would be someone who is in his mid-thirties, is eight to ten years out of law school, has four or more years of tax litigation experience as an IRS or Justice Department lawyer, and was recently promoted to partner in a well-established law firm. We located such a person in a medium-size midwestern city, and found that his billing rate was $\$ 135$ per hour. We do not submit that this is an average fee; the data obviously permit no such inference. We would assert, however, that this is a reasonable fee for a well-qualified tax litigation specialist. 
To be sure, the amended provisions permit larger awards to be made in some cases. But the $\$ 75$ per hour cap applies "unless the court determines that an increase in the cost of living or a special factor, such as the limited availability of qualified attorneys . . . justifies a higher rate."95 Courts making fee awards may be willing to cite that language to award higher fees. The experience on this point under the counterpart provisions of the EAJA is mixed. ${ }^{96}$

It will be difficult, however, for courts to justify routmely exceeding the $\$ 75$ per hour cap. The first statutory justification-increases in the cost of hiving-should logically be used only to cover adjustments for inflation accruing after 1986; the problem, of course, is that the $\$ 75$ cap was unrealistic in 1986.

The alternative exception - for "special factors"-may be a bit inore elastic, but it will also create problems for any judge conscientiously trying to apply the new code language. There is the threshold question whether a judge can satisfactorily explam finding "special factors" time after time, without acknowledging that the specialness of those factors wears thin after a while. More significantly, a judge must wonder what sort of "special factor" must be found. The one example the statute provides-"liımited availability of qualified attorneys"-is not very helpful. Certainly there is no general shortage of attorneys qualified to handle tax hitigation. A shortage does exist in the sense that a buyer who is unwilling to pay more than about sixty percent of the market price for a service will always find that there is a shortage of qualified service providers at

95. Tax Reform Act of 1986, Pub. L. No. 99-514, $§ 1551$ (c), 100 Stat. 2085, 2752 (to be codified at I.R.C. $\$ 7430($ c)(1)(A)(ii)(III)). The Finance Committee report does not contain further explanation of this provision.

96. The general pattern appears to be one of greater liberality than one might suppose from the words of the statute. In addition to a number of cases that have allowed adjustments for infiation, see, e.g., Massachusetts Fair Share v. Law Enforcement Assistance Admin., 776 F.2d 1066, 1069 (D.C. Cir. 1985), there have been a number of awards made on rather casual findings of "special factors." For example, in Gavette v. Office of Personnel Management, 788 F.2d 753 (Fed. Cir. 1986), the court accepted at face value an affidavit from the claimant's attorney to the effect that there was "a limited availability of attorneys in the Detroit area, who have the capability and willingness to handle proceedings of the nature and kind involved in this case." Id. at 754. Despite the implausibility of this claim as to an apparently routine civil service employment matter, in a legal market of substantial size, and despite the lack of any statistical evidence to buttress the claim, the court allowed reimbursement at the rate of $\$ 100$ per hour. Id. In Aston v. Secretary of Health \& Human Servs., 808 F.2d 9 (2d Cir. 1986), on the other hand, the court reduced an award of $\$ 85$ per hour to the statutory maximum of $\$ 75$ per hour because the district court had failed to name a particular special factor on which it relied, even though there was some evidence in the record that arguably justified a higher award. That evidence suggested that the award to the plaintiff was particularly large for the type of case involved, and that the fee was contingent on a successful outcome. Id. at 11. Some courts have held that a "successful result" and the "contingent nature of success" may be considered as special factors in awarding fee reimbursements. See, e.g., Action on Smoking \& Health v. CAB, 724 F.2d 211, 218 (D.C. Cir. 1984). 
that price. But that is surely a spurious notion of a shortage, somewhat akin to noting a shortage of good, five-cent cigars. After all, section 7430 does not prohibit paying the market price for qualified tax lawyers; it only makes it difficult to obtain full reimbursement at that level.

It is possible that judges will eschew close inspection of the language of section 7430 on this point, rationahizing that Congress meant to provide full reimbursement of attorney fees at reasonable market rates, despite its apparent mability to determme what those rates are. Alternatively, tax lawyers may suddenly discover that it takes them more hours to prepare a case for hitigation than it did when there was no cap on the hourly fee. ${ }^{97}$ Either of these responses would mitigate the problem of under-reimbursement, but one certainly ought to feel uneasy about treating such responses as "solutions" to the problem. A particularly unfortunate aspect of this problem is that it is completely unnecessary; indeed, Congress seems to have gone out of its way to create the problem by settimg a patently unrealistic fee limit. It would have been far better to treat attorney fees in the same manner as Congress treated expert reports and the like: allow the court to award reasonable costs, determined at market rates.

In fairness to Congress, its new rule is superior to the former $\$ 25,000$ cap in at least one respect: the new rule preserves an incentive for the IRS to minimize hitigation costs throughout a proceeding. In contrast, under the overall cap, whatever mcentives were provided by the partial fee-shifting rule disappeared once the actual expenses in a particular case reached the cap. Even this effect is ambiguous, however. Actual experience indicated that the $\$ 25,000$ cap was infrequently invoked because the fees were normally well below that amount.98 In addition, to the extent that the $\$ 75$ per hour limit will only partially reimburse taxpayers for their costs in resisting unreasonable government positions, it diminishes the mtended disincentive for unreasonable government behav-

97. Of course, willfully misstating the hours spent on a case for purposes of augmenting a feereimbursement claim would be fraudulent. Nonetheless, billing practices vary widely. Some lawyers, and some firms, log their time generously, using, for example, conventions such as the quarterhour minimum for all phone calls, regardless of actual length. Others are extremely precise, carefully deducting the ten minutes out of a morning's library research that was spent at the water cooler talking about the Super Bowl. If unreasonable hourly rates are routinely used to limit fee reimbursements, one imagines that a Gresham's law of billing practices would set in, whereby generous, sloppy time records drive out scrupulous ones.

98. In testimony on April 25, 1985 before the Subcommittee on Select Revenue Measures of the House Ways and Means Committee, Roscoe L. Egger, Jr., the then-Commissioner of Internal Revenue, indicated that only three of the first twenty section 7430 fee awards exceeded $\$ 20,000$. Award of Attorney's Fees in Tax Cases: Hearings Before the Subcomm. on Select Revenue Measures of the House Comm. on Ways and Means, 99th Cong., 1st Sess. 18 (1985) (statement of Roscoe L. Egger, Jr., Commissioner of Interual Revenue) [hereinafter Hearings]. 
ior. Evaluation of the old and new rules thus involves an empirical question: Which rule produces the least reimbursement? That question cannot be answered with certainty; what is certain is that a reimbursement rule that imposed no cap on either the hourly or the total costs would produce a more effective disincentive to government unreasonableness than either the new or the old rule.

\section{Net-Worth Limits.}

A statutory scheme that imposed no maximum limit on attorney fee reimbursements, beyond requiring that they be reasonable, may have an adverse budgetary impact. The 1986 amendments to section 7430 provide another, less direct means by which to contain the government's liability for fee shifting. From the effective date of the amendments, individuals with a net worth greater than $\$ 2,000,000$ will be ineligible for reimbursement, as will corporations and other entities liaving a net worth greater than $\$ 7,000,000$ or having five hundred or inore employees. $99 \mathrm{Be}-$ cause relatively few individuals exceed those limits, ${ }^{100}$ the primary impact of this provision is to preclude large corporations from obtaining reinbursements of costs incurred in pursuing their tax claims. ${ }^{101}$

Certainly the cost containment aspect of this eligibility rule has soine virtue, particularly in light of the provision in the Tax Reform Act of 1986 removing the $\$ 25,000$ overall cap on reimbursements. A large corporation with tens of millions of dollars at stake in a tax case may well find it worth spending at least a few million dollars to develop its case. Protecting the fisc against reimbursements of that magnitude seeins prudent.

Nevertheless, section 7430 is not a need-based program; recoveries by taxpayers who fall below these net-worth limits are not preimised on need or ability to pay. Ratlier, the notion underlying section 7430 is that the government should not impose tax litigation costs on citizens unless it has substantial justification for doing so. Is Congress saying that it is acceptable for the government to behave less responsibly toward wealthy individuals and large corporations than toward others?

99. See Tax Reform Act of 1986, Pub. L. No. 99-514, § 1551(d)(2), 100 Stat. 2085, 2752-53 (incorporating net-worth limits contained in 5 U.S.C.A. $\$$ 504(b)(1)(B) (West Supp. 1986)). Taxexempt entities are also exempt from these limits.

100. The Internal Revenue Service estimated that in 1982, there were 407,700 individuals who had a net worth in excess of $\$ 1,000,000$. IRS STATISTICS OF INCOME BULL., Winter 1984-1985, at 1, 8. Presumably, significantly fewer have a net worth in excess of $\$ 2,000,000$.

101. In 1982, only 39,361 U.S. corporations filing returns had total assets in excess of $\$ 10,000,000$. This figure represents only $1.3 \%$ of all active corporations in that year. Those corporations, however, accounted for over $89 \%$ of all corporate net income earned in that year. See Statistics OF INCOME-1982 CoRporation InCOME TAX RETURnS 2 (1985). 
As a practical matter, there is reason not to be too concerned about the government's actions in the large cases. Those cases are subject to close scrutiny at high levels of the IRS and the Justice Department. Neither of these agencies wants to waste resources pursuing hopeless cases, and the risk of doing so inadvertently is reduced in large cases, which merit and normally receive more attention than smaller cases.

Of course, wealthy taxpayers may becoine involved in small tax disputes. Because section 7430 is not a need-based program, they would seem to deserve reimbursement just as much as any other taxpayer who had been subjected to substantially unjustified governinent practices. Although some comfort can be taken in the fact that the costs of proceeding with a small case would not seriously strain the resources of a very wealthy individual, it is still preferable to allow fee reimbursements in such cases; there is simply no adequate basis on which to distinguish wealthy taxpayers from others.

There are also technical problems with the net-worth limits imposed by the 1986 amendments. It is unclear, for exanple, how to apply the limits if the tax issue involves the transactions of one spouse, but the tax hability is determined on a joint return. The net worth of both spouses could be considered, but if two individuals are considered parties, is there a single limit of two million dollars, a single limit of four million dollars, or two separately apphied two million dollar linits (allowing, perhaps, reimbursement of one spouse's share of the costs, but not the other's share, if only one spouse is qualified)? Furthermore, although the routine accounting practices of businesses would normally enable them to state their net worth at a given time with reasonable accuracy, there is no general legal or practical requirement that individuals be likewise prepared to certify their net wortl. Nor are the accounting rules by which individual net worth is measured as well developed as the counterpart rules for businesses.

In sum, it is neither appropriate nor worthwhile to impose networth himitations on individuals. A limitation on corporations, on the other hand, arguably operates as an acceptable substitute for the repealed $\$ 25,000$ per case inaximuin because it controls the overall costs of the reimburseinent prograin.

\section{E. The Burden of Proof.}

Under IRC section 7430, a taxpayer who prevails in his tax dispute may recover his costs only if he "establishes that the position of the 
United States ... was not substantially justified." 102 Thus, on this issue, as on most issues in tax litigation, the taxpayer has the burden of proof. In contrast, under the EAJA, the burden of proof is placed on the government. ${ }^{103}$ Though the Senate bill would have incorporated the EAJA provision into section 7430, 104 the Conference Committee deleted this amendment. ${ }^{105}$ The burden of proof thus remains with the taxpayer in cost reinbursement cases brouglit under section 7430. A brief analysis of the burden of proof is warranted because there is soine merit in the Senate proposal, and because the Senate may raise this issue again.

Analysis of the burden of proof question slould begin with an examination of the type of case in which that question is likely to be important. The prototypical case in which the burden of proof would be critical is one that turns on a factual dispute in which there are two equally credible witnesses who offer contradictory testimony. Perhaps $A$ and $B$ are both disinterested, visually acute, adult bystanders at an automobile accident; $A$ swears that the stopliglit was red, while $B$ maintains equally firmly that it was green. The burden of proof serves as a tie breaker in such cases.

It is unlikely that a substantial number of fee-shifting claims in tax cases would resemble this sort of dispute. The cost-shifting stage of the case would begin when a taxpayer who lias prevailed on the merits of the substantive tax dispute alleges that the IRS was not merely wrong, but that it acted without substantial justification. In response, the government would describe its legal theory and explain why it had a good faith belief that the precedents it relied on gave it a substantially justified basis for believing it would prevail on the substantive issue. ${ }^{106}$ In other words, the costs disputes involve mostly matters of law, not of fact. Matters of law may be closely balanced, but judges are expected ultimately to reacl conclusive outcomes on legal questions without resorting to tie breakers. ${ }^{107}$

One would expect, of course, that factual disputes would arise in some fee-shifting cases. These would typically be cases in which the IRS

102. I.R.C. $\$ 7430$ (c)(2)(A)(i) (1982), as amended by Tax Reform Act of 1986, Pub. L. No. 99514, § 1551(d)(1), 100 Stat. 2085, 2752.

103. See H.R. ReP. No. 1418 , 96th Cong., 2 d Sess. 10-11, reprinted in 1980 U.S. CodE CoNg. \& ADMIN. NEWS 4984, 4988-89.

104. See Conference RePort, supra note 49 , at 801 .

105. Id. at 802 .

106. See, e.g., Penner v. United States, 584 F. Supp. 1582, 1583-84 (S.D. Fla. 1984); Hallam v. Murphy, 586 F. Supp. 1, 3 (N.D. Ga. 1983).

107. See Washington v. Heckler, 756 F.2d 959, 962 (3d Cir. 1985) ("[D]eterminations of whether a particular iuterpretation of the law is plausible or colorable [are] regarded as conclusions of law and reviewed as such." (citing Spence v. NLRB, 712 F.2d 539, 563-64 (D.C. Cir. 1983))). 
has made a mistake of fact. For example, suppose the IRS attempted to collect a tax owed by $A$ through a levy on a bank account held by $A$ as a trustee for the benefit of $B$, and that the bank incurred substantial legal costs in resistimg the collection by means of an interpleader. ${ }^{108}$ Presumably, the IRS could, despite its mistake, satisfy the court that it acted justifiably if the mistake was reasonable from its viewpoint. For instance, if bank records showed that $A$ was the owner of the account, without indicating that he was merely a trustee with no beneficial ownership, and if the bank had an opportumity to demonstrate that $A$ was not the beneficial owner of the account but made no effort to do so, the IRS would probably be found to have acted with substantial justification. But under these circumstances-in keeping with the general maxim that burdens of producing evidence should be placed on those who can most conveniently discharge those burdens 109 - the burden should be on the governneent, not on the taxpayer, as it presently is under IRC section 7430.

Even in this hypothetical, however, the assignment of the burden of proof may not matter very much. Suppose, for example, that the current IRC rule applies in the hypothetical, so that the bank has the burden of proving that the IRS acted without substantial justification. In the underlymg substantive case, the bank would have proven that it never held any assets that could properly have been available for collection of $A$ 's tax liability. By itself, this evidence would probably discharge the bank's obligation to present a prima facie case for cost reimbursement. The IRS would then raise as a defense the defectiveness of the bank's records and

108. The facts of this hypothetical resemble those of Prudential-Bache Sec., Inc. v. Tranakos, 593 F. Supp. 783, 784-85 (N.D. Ga. 1984). In Prudential-Bache, and in the hypothetical, it is the financial institution-not the trustee-who would maintain the fees action against the government. Id.

A number of other cases have involved mistakes of fact, delays, and other alleged bureaucratic misdeeds of the IRS. See, e.g., Baker v. Commissioner, 787 F.2d 637, 638-41 (D.C. Cir. 1986) (IRS ignored taxpayer's claim that he was not treated the same as his identically situated coworkers, who had made claims to which the IRS had acceded); Reggi v. United States, 632 F. Supp. 5, 5-6 (N.D. Cal. 1986) (bureaucratic delay in processing tax refund); Peavy v. United States, 625 F. Supp. 974, 976 (D. Colo. 1986) (14-month delay prior to settlement; failure of government representative to appear at settlement conference). In one case, the IRS sent notice of an upcoming audit to the former address of the taxpayers, who never received the notice and failed to appear at the audit. Notice of adjustment of their tax liability and notice of a deficiency were sent to an address where the taxpayers had never lived. Kaufman v. Egger, 758 F.2d 1, 2 (1st Cir. 1985). During the same time period, the IRS corresponded with the taxpayers at their correct address coneerning unrelated tax matters. Id. at $2 \mathrm{n} .2$. The taxpayers instituted a successful action for injunctive relief after the IRS seized a refund payment and sought additional tax payments. Id. at 2 . Affirming the award of attorney fees to the taxpayers, Judge Torruella observed: "The present case zeros in on one of many unnecessary tribulations that can be brought to bear upon the unsuspecting citizenry by today['s] computerized bureaucracy. It also requires our interpreting one Congressional attempt to grant the public some relief from such bungling." Id. at 1-2.

109. See R. POSNER, supra note 28 , at 520-21. 
the bank's failure to show that $A$ was not the beneficial owner of the account. The IRS's argument is essentially an affirmative defense, which imposes a burden of proof on the party that raises it. Thus, it would seem that both the conduct of the cost reimbursement hearing and its outcome would be the same regardless of the formal assignment of the burden of proof.

A review of the existing case law under the EAJA and IRC section 7430 confirms this view. A reversal of the burden of proof would change the outcome in few, if any, cases. In Prudential-Bache Securities, Inc. v. Tranakos, ${ }^{110}$ on which the bank hypothetical is based, the financial institution obtained reimbursement of its costs despite having the burden of proof under section 7430.111 It does not appear from the court's discussion that Prudential-Bache was required to produce any evidence other than that which was convemiently available to it: that it had notified the IRS that the delinquent taxpayer was not the beneficial owner of the account. ${ }^{12}$ If there were other materials im the IRS file that made it reasonable for the governinent to proceed with the levy anyway, the IRS should have produced that evidence in the costs reimbursement case. This was a "burden" that the IRS apparently could not satisfy. ${ }^{113}$

The foregoing analysis suggests that the burden of proof simply doesn't matter very much; this, of course, provides hittle reason for preferring one allocation of the burden of proof over the other. It seems mildly preferable, however, to place the burden of proof on the government because the IRS will be in a superior position to provide relevant evidence on most of the factual disputes in costs reimbursement cases. Explicitly placing the burden on the government obviates the need for any "affirmative defense" analysis without unduly hampering the governinent.

Roscoe Egger, the then-Commissioner of Internal Revenue, testified that placing the burden of proof on the government might make taxpayers less willing to stipulate to the facts of their cases, which would in turn make processing tax disputes more difficult and time consuming. ${ }^{14}$ This

110. 593 F. Supp. 783 (N.D. Ga. 1984).

111. Id. at 787.

112. Id. at $785-87$.

113. In another case, a taxpayer showed that the IRS had ignored his claim that his identically situated coworkers had obtained favorable settlements with the IRS and that he was forced to obtain couusel in order to obtain the same disposition. Baker v. Commissioner, 787 F.2d 637, 643-44 (D.C. Cir. 1986). Judge Ginsburg held that the taxpayer made a sufficient showing to be entitled to a hearing on his claim for attorney fees. Id. at 644. The court noted that "a rational basis" for the IRS's conduct might be found at the hearing, but that the Tax Court had to give the taxpayer's claim full consideration. Id.

114. Hearings, supra note 98 , at 14-15. 
argument is unconvincing. Given that the taxpayer has the burden of proof as to all facts in the substantive dispute, the primary effect of the stipulation process is to relieve the taxpayer from proving the essentially uncontested facts of his case. Thus, the taxpayer has a strong incentive to cooperate in the stipulation process; it is difficult to see how the fees question affects this incentive. Furthermore, the Tax Court rules make stipulation of uncontested facts mandatory, ${ }^{115}$ a requirement that is given force by a rule that permits motions to compel stipulation. ${ }^{116}$ Finally, another new provision of section 7430 (added by the Tax Reform Act of 1986) permits the court to deny fee awards that could otherwise be made if the court finds that "the prevailing party has unreasonably protracted [the] proceedings." 117 Failure to stipulate essentially uncontested facts would surely provide grounds for invoking this bar to reimbursement.

Counterintuitively, it may even be preferable from the IRS's viewpoint to bear the burden of proof on this issue. ${ }^{118}$ As noted above, the IRS will generally be in a superior position to provide evidence on factual issues concerining its justification for bringing the case. If the taxpayer bears primary responsibility for adducing evidence on these issues, it would be appropriate for the court to permit broad discovery against the IRS. Placing the burden on the IRS not ouly would relieve the taxpayer of the costs of conductimg such discovery, but might also, in many cases, impose less cost even on the IRS than would compliance with wide-ranging discovery requests. Thus, imposing the burden of proof on the IRS to show that it acted with substantial justification would appear to produce substantial efficiency gams. If Congress reconsiders section 7430 , it should examine agam the merits of the Senate position on this question.

\section{CONCLUSION}

The fee-shifting rules of the IRC are an attractive compromise between the American and the English rules. Parties are deterred from acting unreasonably by the prospect of liability for section 6673 penalties or for attorney fees under section 7430; thus, the IRC incorporates the most favorable aspect of the English rule. At the same time, the IRC rules do not deter parties with reasonably good claims from engaging in litigation. Attorney fees or penalties are not awarded automatically to

115. TAX CT. R. Prac. 91(a).

116. TAX CT. R. Prac. 91(f).

117. Tax Reform Act of 1986, Pub. L. No. 99-514, $\S 1551$ (b), 100 Stat. 2085, 2752 (to be codified at I.R.C. $\$ 7430$ (b)(4)). The language of this provision is mandatory. Still, because the denial of reimbursement depends on a finding by the court that the taxpayer has acted unreasonably, substantial discretion is in fact left with the court.

118. Obviously, the government disagrees. See supra text accompanying note 114. 
the prevailing party; only parties acting unreasonably must pay fees or penalties. Moreover, both parties still have an incentive to incur only necessary legal fees because even parties with strong claims cannot be assured of a fee award.

None of the changes Congress enacted in the Tax Reform Act of 1986 radically alters the IRC rules. The preceding generalizations accurately describe the IRC fee-shifting provisions both before and after the section 7430 annendments. The worst downside risk involved in the changes is that Congress may wish to modify, or even reverse, some of the changes that we believe will cause instability and uncertainty.

Nevertheless, the 1986 amendments, taken as a whole, probably do not represent improveinents in the tax fee-shifting rules. It is inore likely that they will marginally detract from the fairness and efficiency of the rules as they existed before the amendments. Substituting a "substantial justification" test for a "reasonableness" test, for example, is likely to be a poor idea, particularly if courts apply the language of the EAJA committee reports. These reports suggest that the "substantial justification" test is meant to represent a higher standard than is the "reasonableness" test. ${ }^{119}$ In particular, the new test seems to inandate fee reimbursement in cases where the government is found to have abused its discretion by acting arbitrarily or capriciously. ${ }^{120}$ In a number of areas of our tax laws, however, Congress has granted broad discretion to the governinent; the governinent's action in those areas can be overturned only if a court finds the action to be arbitrary and capricious. ${ }^{121}$ Thus, every such case that the governinent loses necessarily involves a finding that it acted arbitrarily and capriciously. If those findings give rise to attorney-fee claims, as would appear to be the case under the EAJA standard, the result would be virtually automatic fee shifting in a large number of tax cases, a result that Congress presuinably did not intend.

Sinilarly, the ainendment inandating that courts, when determining justifiability, exannine the prehitigation position of the government-and not merely the posture taken in court-seems unwise. Section 7430 cannot, and was not intended to, cover all expenses for taxpayers who win tax disputes; a line must be drawn somewhere, below which taxpayers must bear their own costs, in order to conserve both the financial and personnel resources of the IRS. Drawing the line at litigated cases ineant that the courts had to hear reimbursement disputes only after having already considered the merits of the underlying case. Under the new

119. See supra notes $59-61$ and accompanying text.

120. See supra note 61 and accompanying text; see also H.R. REP. No. 120, 99th Cong., 1st Sess., pt. 1, at 9, reprinted in 1985 U.S. CodE CoNG. \& ADMIN. NEws 132, 138.

121. See supra notes $62-69$ and accompanying text. 
rules, courts must examine the merits of dismissed cases in order to evaluate whether the government was justified in docketing a case that it subsequently decided to concede.

The new $\$ 75$ per hour cap on attorney fees has strengths and weaknesses that are different from those of the former $\$ 25,000$ overall limit on fees in any one case. On balance, however, the new rule is no better than the old one. The new net worth limits are similarly problematic: they help to control costs, but convey the unfortunate message that it is acceptable for the government to abuse the wealthy. The individual net worth limits also require the development of definitions and certifications of net worth that are largely unnecessary.

All of these changes serve to conform the section 7430 rules to the counterpart provisions of the EAJA; and this seems to have been a major desideratum of the amendments, at least in the Senate. It is unclear, however, why conformity between the two sets of rules is particularly important. It is almost as though Congress were pursuing an aesthetic value here-symmetry for its own sake. In this situation, however, the symmetry achieves nothing. The tax bar is by and large a specialized one that has hittle contact with other types of federal litigation, and in any event must operate under the special procedural rules of the Tax Court. ${ }^{122}$ Moreover, the considerations that apply to tax cases do not always apply to federal cases generally. ${ }^{123}$ Congress originally recogmized the merit in differentiating the two sets of cases by creating two sets of rules. It was wise to do so, and it would be wise to resist future temptations to conform those rules inerely for the sake of conformity.

122. In addition to a substantial set of statutory provisions governing Tax Court procedure (codified at I.R.C. $\S \S 7451-7465$ ), there are 247 procedural rules that have been promulgated by the Tax Court itself. See 10 Fed. Taxes (P-H) If 39,009.5-39,239.7 (1987). In addition, because section 7430 is not, and probably cannot be, fully conformed to the counterpart provisions of the EAJA, it will always be necessary for lawyers arguing section 7430 cases to be familiar with that specific statute, rather than relying on prior knowledge based on EAJA cases they may have tried. See, e.g., Treas. Reg. $\S 301.7430-1$ (1984) (establishing special section 7430 rules on exhaustion of administrative remedies).

123. In general, the arguments in this article have not depended on making distinctions of this sort. That is, the article evaluates section $\mathbf{7 4 3 0}$ rules in the context of a tax controversy, without regard to whether a counterpart rule would make sense in the broader federal litigation context to which EAJA rules apply. If one were to engage in a comparative analysis of the EAJA and section 7430, however, several special characteristics of tax cases would have to be considered, including the following: the potential number of disputes, in view of the one hundred million annual returns and two million annual audits, is huge; the administrative apparatus for handling disputes is much more elaborate in the tax area than in most areas that generate suits against the government; and taxpayers generally have a wider choice of forum than other federal litigants because most tax eases can be brought in the Tax Court, a federal district court, or the United States Claims Court. 